\title{
Grammars of Classical Arabic in Judaeo-Arabic
} An Overview

\author{
Nadia Vidro \\ University College London, London, United Kingdom \\ n.vidro@ucl.ac.uk
}

\begin{abstract}
This article presents an overview of medieval Classical Arabic grammars written in Judaeo-Arabic that are preserved in the Cairo Genizah and the Firkovich Collections. Unlike Jewish grammarians' application of the Arabic theoretical model to describing Biblical Hebrew, Arabic grammars transliterated into Hebrew characters bear clear evidence of Jewish engagement with the Arabic grammatical tradition for its own sake. In addition, such manuscripts furnish new material on the history of the Arabic grammatical tradition by preserving otherwise unknown texts. The article discusses individual grammars of Classical Arabic in Judaeo-Arabic and tries to answer more general questions on this little known area of Jewish intellectual activity. An analysis of the corpus suggests that Jews who copied and used these texts were less interested in the intricacies of abstract theory than in attaining a solid knowledge of Classical Arabic. Court scribes appear to have been among those interested in the study of Classical Arabic grammar.
\end{abstract}

\section{Keywords}

Arabic grammatical tradition - Jews - medieval - transliterations - Cairo Genizah Firkovich Collections

\section{Introduction}

Medieval Jewish grammatical interests centered around the study of the language of Jewish Scripture-Biblical Hebrew. Although recent research ${ }^{1}$ sug-

1 Becker, Arabic Sources of R. Jonah ibn Janāh; idem, Arabic Sources of Isaac ben Barūn; Basal, "Part one". 
gests that some Jewish grammarians were also versed in Muslim theories developed for the study of Classical Arabic, the general extent of Jews' knowledge of the Arabic grammatical tradition is unclear. Observing that a preeminent Hebrew grammarian Jonah ibn Ğanāh (c. 990-1055) worked with Arabic grammatical concepts and terminology without explaining them to the reader, D. Becker suggested that Ibn Ğanāh expected the audience to be familiar with Arabic grammatical works. ${ }^{2}$ In contrast, Ibn Ğanāh himself lamented that Jews "conversant and skilled in the science of the Arabic language" were few. ${ }^{3}$

A number of treatises on the grammar of Classical Arabic are preserved in collections of Jewish manuscripts, such as the Cairo Genizah collections and the Firkovich Collections in the Russian National Library in St. Petersburg. Some of these manuscripts are in Arabic script, others are transliterated into Hebrew characters. While there is little doubt that Jewish scholars could read and study works on Classical Arabic grammar penned in Arabic script, it is the Judaeo-Arabic copies that most clearly testify to Jews' active engagement with this material. Like any transliterations, they represent a means of appropriating knowledge that originated outside of the Jewish culture ${ }^{4}$ and demonstrate Jewish interest in Classical Arabic grammar for its own sake rather than as a theoretical framework for analysing Biblical Hebrew.

Until now, two grammars of Classical Arabic in Judaeo-Arabic have been published and analysed ${ }^{5}$ and some more have been identified in printed and electronic catalogues. However, no attempt has been made to assemble and assess a corpus of Classical Arabic grammars in Judaeo-Arabic, and this area of Jewish intellectual production remains under-appreciated and largely unknown.

The purpose of this article is to present an overview of all fragments of Classical Arabic grammars copied in Judaeo-Arabic that are known today. The article pieces together manuscripts scattered in the Cairo Genizah and the Firkovich Collections and looks at the individual fragments' contents and Muslim sources. In addition, the article tries to address more general questions, such as who was interested in learning the grammar of Classical Arabic, what kinds of grammars Jews were interested in and whether Jews only transliterated or also composed some of the grammars that we possess today.

2 Becker, Arabic Sources of R. Jonah ibn Janāh, pp. v, 27; idem, "The dependence," p. 141.

3 Ibn Janāh, Kitāb al-Lumac, "Book of Variegated Flower-Beds", p. 8.

4 See Langermann, "Arabic writings," pp. 137, 139-140. On the inter-cultural appropriation of knowledge see Sabra, "Appropriation".

5 Basal "Mediaeval Jewish and Muslim cultures;" Vidro, Kasher, "A Kūfan primer." 


\section{Reconstruction and Description of Individual Grammars}

\section{1 \\ Judaeo-Arabic Versions of Known Muslim Grammars}

1) RNL Evr Arab II 290, 12 Folios, 13th-Century Handwriting

This grammar was identified by $\mathrm{N}$. Basal as a fragment of an adaptation of alLuma'fíl-'arabiyya (al-Luma'fil-nahww) "Book of Variegated Flower-Beds in the Arabic Language" ("Book of Variegated Flower-Beds in Grammar") by a prominent 1oth century grammarian Abū l-Fatḥ 'Utmān Ibn Ğinnī (d. 392/1002). ${ }^{6}$ Al-Luma' is a textbook of Classical Arabic grammar, dealing primarily with syntax, but also with phonology and morphology, and is one of the more advanced pedagogical grammars of Arabic, produced due to the need to promote a standard Arabic. ${ }^{7}$

The Judaeo-Arabic adaptation follows the plan of the original work but is not a straightforward representation of al-Luma'. The surviving folios contain chapters on conjunction, negation, the sisters of inna, syntactic constructions requiring certain cases, and the vocative. Some chapters are transmitted verbatim, from others only selected passages are copied, others still are represented by summaries of the material in Ibn Ğinnī with additions from other grammars, mainly Kitāb al-Ğumal fı l-naḥw "Book of Grammatical Propositions" by Abū l-Qāsim al-Zağǧāḡōî, another advanced pedagogical grammar. ${ }^{8}$ Many Qur’ānic examples are added in the adaptation that are not found in the original work.

2) T-S NS $301.25^{\mathrm{r}, 9}$, Page, 12th-13th-Century Handwriting

The fragment contains a passage from Kitāb al-Ǧumal fíl-naḥw "Book of Grammatical Propositions" by Abū l-Qāsim 'Abd al-Raḥmān b. Isḥāq al-Zağğāḡī, a 1oth century Arab grammarian (d. 339-340/949-50). Kitāb al-Ğumal fi l-naḥw is an introduction to Classical Arabic grammar written for beginners, in which al-Zağğāğ̄̄ presents the rules of grammar accompanied by multiple examples and explains grammatical terminology. ${ }^{10}$

The preserved text belongs to The Chapter on Knowing the Markers of Inflection (bāb ma'rifat 'alāmāt al-i'rāb) and forms the closing section of the

6 Basal, "A medieval Jewish grammar;" idem, "Mediaeval Jewish and Muslim cultures".

7 See Carter, "Grammatical tradition".

8 Basal, "Mediaeval Jewish and Muslim cultures," pp. 231-233. On Kitāb al-Ğumal see below, item 2.

$9 \quad$ Edited and studied in Vidro, "Arabic vocalisation." Transcribed without vocalisation and translated into Hebrew on the website of the Friedberg Jewish Manuscript Society https:// fjms.genizah.org.

See Sezgin, GAS, vol. 9, pp. 88-94; Zabara, Perspectives; Binaghi, La postérité andalouse . 
chapter. ${ }^{11}$ Below, The Chapter On Verbs is announced but is not copied, leaving a large empty space at the bottom of the page. The text is consistently vocalised with Arabic signs, which occasionally reflect non-standard pronunciation (e.g. פגמיע with a sandhi-type elision of the short /a/) and imperfect knowledge of Classical Arabic inflection rules (e.g. ללריפַy with a nominative ending after a preposition).

The consistent vocalisation in T-S NS $301.25^{\mathrm{r}}$ is significant for determining the fragment's function. Al-Zağğăğ̄̌is Kitāb al-Ğumal was traditionally used in the classroom to teach students the basics of the Classical Arabic language and grammar. $^{12}$ It is clearly with the same purpose that this work was transliterated into Hebrew characters. That the single currently identified part of Kitāb al-Ğumal in Hebrew characters is the chapter on inflection, and the following chapter on verbs was not copied even though enough space remained on the page to do so, may indicate that only a portion of the book was transcribed and vocalised, possibly as a vocalisation exercise. It seems fitting that a basic text on grammatical cases, which mainly deals with vowels and ends with a summary of all case markers, should be used as a sample text to practice one's vocalising skills. The imperfect vocalisation of the fragment may indicate that this is not a teacher's work to be copied by future students but the product of a learner who has not yet attained full mastery of this subject.

RNL Evr Arab II 185 (25 Fols.), RNL Evr Arab II 253 (1 Folio), RNL Evr Arab I 4631 (1 Folio), ${ }^{13}$ 12th-Century Handwriting

The manuscripts belong to a partially preserved Judaeo-Arabic copy of Šarh Mulhat al-irāab, a commentary on the didactic grammatical poem Mulhat ali'rāb "Witty Poem on Inflectional Endings" by a renown Arabic author Abū Muhạammad al-Qāsim b. 'Alī l-Ḥarīī (446/1054-516/1122). ${ }^{14}$ The grammatical poem was composed by al-Harīin in c. 504/1110 at the prompting of the Chris-

11 Al-Zağğāḡī, Kitāb al-Ğumal, pp. 3-6, esp. p. 6.

12 Carter, "Grammatical tradition," Binaghi, La postérité andalouse, pp. 155-156, 158-159.

13 I thank Dr José Martinéz Delgado (University of Granada) for drawing my attention to these manuscripts. The correct order of pages is: RNL Evr Arab II $1855^{\mathrm{v}}, 5^{\mathrm{r}}, 2^{\mathrm{r}}, 2^{\mathrm{v}}, 4^{\mathrm{r}}, 4^{\mathrm{v}}$, $3^{\mathrm{v}}, 3^{\mathrm{r}}, 1^{\mathrm{v}}, 1^{\mathrm{r}}$; RNL Evr Arab II 253 ${ }^{\mathrm{r}}$, RNL Evr Arab II 253 ${ }^{\mathrm{v}}$; RNL Evr Arab II $1856^{\mathrm{v}}, 6^{\mathrm{r}}, 7^{\mathrm{r}}$, $7^{\mathrm{v}}, 15^{\mathrm{v}}, 15^{\mathrm{r}}, 8^{\mathrm{r}}, 8^{\mathrm{v}}, 16^{\mathrm{r}}, 16^{\mathrm{v}}, 10^{\mathrm{r}}, 10^{\mathrm{v}}, 12^{\mathrm{r}}, 12^{\mathrm{v}}, 11^{\mathrm{v}}, 11^{\mathrm{r}}, 13^{\mathrm{v}}, 13^{\mathrm{r}}, 18^{\mathrm{r}}, 18^{\mathrm{v}}, 20^{\mathrm{r}}, 20^{\mathrm{v}}, 19^{\mathrm{r}}, 19^{\mathrm{r}}, 17^{\mathrm{v}}, 17^{\mathrm{r}}$, $14^{\mathrm{r}}, 14^{\mathrm{v}}, 21^{\mathrm{r}}, 21^{\mathrm{v}}, 9^{\mathrm{r}}, 9^{\mathrm{v}}, 22^{\mathrm{v}}, 22^{\mathrm{r}}, 25^{\mathrm{r}}, 25^{\mathrm{v}}, 24^{\mathrm{v}}, 24^{\mathrm{r}}, 23^{\mathrm{r}}, 23^{\mathrm{v}}$, RNL Evr Arab I $463^{\mathrm{r}} ;$ RNL Evr Arab I $4631^{\mathrm{v}}$.

14 RNL Evr Arab II 185 is identified as Kitāb al-I'rāb by al-Harīin in the catalogue of the National Library of Israel and as Šarh Mulhat al-irāa by the same author on the manuscript's fly-leaf. A comparison of the fragments shows that RNL Evr Arab II 253 and RNL Evr Arab I 4631 originally belonged to the same codex. 
tian chief physician of Baghdad, Abū l-Fatḥ Hibatallāh Ibn al-Tilmīd. Al-Harīī wrote the commentary in the same year. ${ }^{15}$ Composed for non-specialists, the commentary is written in a simple language with multiple examples, many taken from poetry. ${ }^{16}$

Copied in the 12th century, the Judaeo-Arabic text is an early witness of $\breve{S} a r h$ Mulhat al-irāab. The following chapters fully or partially survive: on the noun, on the verb, on the particle, on the indefinite and the definite, on the division of verbs, on the inflection, on the inflection of triptote nouns, on the initial item and the predicate, on the agent, on the patient, on the sisters of zanantu, on the exclamatory construction, on the construction of instigation, on the construction of warning, on the sisters of inna, on the sisters of kāna, on $m \bar{a}$ of negation, on the vocative, on the apocopation (of the vocative), on the diminutive, on the appositives, on diptotes, on poetic license, on numerals. ${ }^{17}$

A comparison of the manuscripts with a printed Arabic script edition indicates that the Judaeo-Arabic version is a straightforward copy without significant changes. The only deviations are occasional omissions of short bits of text, such as examples and Islamic honorifics. The text carries relatively many transliteration mistakes conditioned by the shapes of letters and letter combinations in Arabic script. The mistakes in transliteration are particularly common in chapters dealing with finer details of Classical Arabic, which the copyist may have been less familiar with, e.g., the case endings in different vocative construction.

Judaeo-Arabic Grammars of Classical Arabic that Could Not Be Identified with Known Muslim Works

4) T-S AR 5.17, ${ }^{18} 1$ Folio, 13 th-Century Handwriting

The fragment is part of an unidentified short standard work on Arabic grammar. The surviving text is devoted to nominal and verbal inflection (íräb), defined as changes at the end of words due to a syntactic factor ('ämil), visible in the surface phonological structure of sound forms and virtually present in weak forms. It looks at possibilities of actualising cases in nouns beyond the unmarked triptote paradigm, including various types of defective nouns, the

\footnotetext{
15 Hämeen-Anttila, "Abū Muḥammad al-Q̣āsim al-Ḥarīrî," p. 74.

16 See also al-Harīīi, Šarh Mulhat al-i'rāb, p. 36.

17 This corresponds to the following pages in al-Ḥarīī, Šarh Mulhat al-i'rāb: 5-15, 17-18, 28 33, 77-81, 84-86, 94-97, 139-145, 147-160, 163-168, 192-200, 214-224.

18 Transcribed and translated into Hebrew on the website of the Friedberg Jewish Manuscript Society https://fjms.genizah.org. The text starts on what is currently the verso of the fragment and ends on recto.
} 
five nouns $a b, a h, f \bar{u}$, ham and $\underline{d} \bar{u}$, dual and sound masculine plural forms. It then goes on to discuss each case and mood separately, but breaks off in the middle of a discussion of the nominative.

5)

$$
\begin{aligned}
& \text { T-S Ar.31.254 (1 Folio), T-S 24.31 (1 Folio) and T-S AS } 155.132 \text { (1 } \\
& \text { Folio), }{ }^{19} \text { Late 11th-Century Handwriting }
\end{aligned}
$$

The fragments are part of a rotulus that originally held a petition to a dignitary penned in large Arabic characters. ${ }^{20}$ Such state documents were written on only one side of the paper and laid out with wide spaces between the lines, which made them very attractive for recycling as writing paper for other texts. ${ }^{21}$ In the rotulus, a Judaeo-Arabic grammar of Classical Arabic has been copied on the blank side and between the lines, penned upside down compared to the original text. It is most likely that the Judaeo-Arabic text is in the hand of the prolific court scribe Hillel b. 'Eli, who wrote numerous Genizah documents between $1066-1107 .^{22}$

The grammar is divided into short chapters dealing primarily with the correct cases and moods in different syntactic constructions, such as the predicative construction, annexation, circumstantial clauses, the passive, etc., lists of operators that require certain cases and moods, the formation of nisba adjectives, and the spelling of final weak verbs. Each chapter summarises the subject matter in one or two sentences and provides a large number of examples.

An analysis of the fragments shows that this grammar does not belong to the mainstream of the Arabic grammatical tradition. The text can be identified as a pedagogical grammar representing the so-called Küfan school of grammar. In the Arabic grammatical tradition two schools are distinguished, the Küfan and the Bașran. Although the authenticity of the schools is debated, ${ }^{23}$ distinctive terminology and grammatical theories are consistently ascribed to them in medieval Arabic sources. ${ }^{24}$ The terminology, notions and theories embraced in T-S Ar.31.254, T-S 24.31 and T-S AS 155.132 correspond with those commonly

19 Published in Vidro, Kasher, "A Kūfan primer." The correct order of pages is: T-S Ar. $31.254^{\mathrm{r}}$, T-S 24.31 ${ }^{\mathrm{r}}$, T-S AS $155.12^{\mathrm{r}}$, T-S AS $155.12^{\mathrm{v}}$, T-S $24.31^{\mathrm{v}}$ (the Judaeo-Arabic text is not found on the verso of T-S Ar. 31.254).

20 On petitions addressed to dignitaries below the rank of a caliph see Khan, Arabic Legal, pp. 379-409.

21 On this practice, see Rustow, "A petition," pp. 17, 22.

22 Weiss, Hillel ben Eli.

23 An up-to-date overview of the different views of modern scholars is Baalbaki, "Introduction," esp. pp. xxxix-xlii.

24 See, e.g., Weil, Streitfragen. 
presented in the sources as Küfan. ${ }^{25}$ The shibboleth Küfan terms used in the fragments are $q a t^{\varsigma}$ for circumstantial qualifier and șifa for locative qualifier, for which the corresponding Bașran terms are $h \bar{a} l$ and zarf respectively. ${ }^{26}$ In the chapter on $q a t^{c}$, the author explicitly dissociates himself from the Basrans: while consistently using $q a t^{\prime}$ to denote circumstantial qualifier, the author remarks that the Bașrans' term for qaț is ha $\bar{a} . .^{27}$ It is unfortunate that several words are missing in the manuscript where the author most probably alludes directly to the group that uses the term $q a t^{\prime}$, viz. his in-group. A famous Küfan theory embraced in the grammar is that infinitives are derived from finite verbs, i.e. hurūğ is derived from harağa. In contrast, Bașran grammarians maintained that verbal derivation occurs in the opposite direction, from infinitives to finite verbs. ${ }^{28}$

A conspicuous feature of the Judaeo-Arabic version of this grammar is the occurrence of numerous mistakes in transliteration. These mistakes demonstrate that the grammar was copied into Hebrew characters from an Arabic script Vorlage rather than composed directly in Judaeo-Arabic. The mistakes in transliteration reveal that the scribe, in all probability Hillel b. 'Eli, was not a proficient reader of cursive Arabic texts. Moreover, at the time of copying he was not educated in Classical Arabic grammar, for he clearly did not understand the grammatical analysis. One of the most conspicuous demonstrations of this is found in the chapter on the past form of final weak verbs, where the unpointed tooth element in $\mathrm{s}$ is consistently interpreted as $b$ instead of $y$, which results in the chapter discussing final waw and final $b \bar{a}^{\prime}$ verbs.

$$
\text { Mosseri I.73.1 (1 Folio), T-S Ar 5.45 }{ }^{29} \text { (1 Bifolio and } 1 \text { Folio), }
$$
12th-Century Handwriting

The fragments are in the hand of the well-known court scribe and poet Nathan b. Samuel Nezer ha-Haverim (or he-Haver)..$^{30}$ Nathan b. Samuel was born and

25 For a detailed discussion of the fragments' Kūfan nature see Vidro, Kasher, "A Kūfan primer," pp. 215-234.

26 Vidro, Kasher, "A Kūfan primer," pp. 227, 229.

27 Vidro, Kasher, "A Kūfan primer," p. 183.

28 Vidro, Kasher, "A Kūfan primer," pp. 183-184, 231.

29 T-S Ar 5.45 is transcribed and translated into Hebrew on the website of the Friedberg Jewish Manuscript Society https://fms.genizah.org. The correct order of pages is Mosseri I.73.1 ${ }^{\mathrm{r}}$, Mosseri I.73.1 $1^{\mathrm{v}}$, T-S Ar. 5.45 $\mathrm{P1}^{\mathrm{v}}$ left, T-S Ar 5.45 $\mathrm{P}^{\mathrm{r}}$ right, T-S Ar 5.45 $\mathrm{P}^{\mathrm{r}}$ left, T-S Ar 5.45 $\mathrm{P}^{\mathrm{v}}$ right, T-S Ar $5.45 \mathrm{P}_{2}{ }^{\mathrm{r}}$, T-S Ar $5.45 \mathrm{P}_{2}^{\mathrm{v}}$.

30 For other literary texts in his hand see T-S Ar 48.121 and T-S Misc 35.48, the account of the 
started his scribal career in Damascus, moved to Egypt in 1127 and was active until his death in 1163 as a scribe of the Palestinian academy at the court of the gaon Mașliah ha-Kohen b. Solomon. ${ }^{31}$

The text preserved in the fragments is not a coherent treatise but an eclectic compilation of grammatical materials put together by association, with additions from other disciplines, such as orthography, philosophy, and biographical literature. The compilation is not well structured: sometimes a chapter is started, left unfinished as the compiler diverges into another subject and then resumed or even started again. The text stops abruptly in the middle of a sentence leaving most of the final page empty. ${ }^{32}$ It is most likely that this is a private compilation prepared in the process of studying Classical Arabic grammatical theories. It is possible that this compilation was put together by Nathan b. Samuel Nezer ha-Haverim.

The discussed topics are: types of predicates, parts of speech, principles of inflection, the actualisation of moods and cases in words of different patterns including diptosis, and negation particles. The level of text oscillates between a basic statement of linguistic facts and a more abstract discussion of theoretical issues. Parts of The Chapter on Parts of Speech and of The Chapter on Inflection are identical with corresponding sections of a short grammar Al-Tuffäha l-nahww "The Apple of Grammar" by Abū Ğafar al-Naḥhās (d. 338/949). ${ }^{33}$ In the more theoretical sections, the fragment deals with such issues as why verbs are secondary to nouns, why nouns cannot have the apocopate form (ğazm), why certain factors cause diptosis, etc. A section on graphic signs (šadda, wașla, tanwin, etc) is also included, which is common in treatises on Arabic orthography but not in Muslim grammars.

The most noteworthy feature of this text are the cited authorities. The fragments give four definitions of parts of speech: by Sībawayhi (d. c. 180/796), by 'Alī b. Abī Ṭālib (c. 6oo-4o/661), by Aristotle and by al-Dumayk (c. 457/106o$510 / 1117)$.

1) Sībawayhi's definition of the noun:

Babylonian academies by Nathan ha-Bavli (for an identification of the hand see Gil, In the Kingdom of Ishmael, vol. 2, pp. 40-47) and Mosseri II.214, a piyyut fragment where the name Nathan b. Samuel hazaq is marked on verso.

31 See Fleisher, "From the diwan," pp. 143-146.

32 In the empty space, two secondary Hebrew texts are copied in large square letters and using a different ink: a variation of the sentence that brings together all letters of the alphabet (see http://blog.nli.org.il/writing_lesson, accessed on 13 November 2017) and a list of forbidden slaughter techniques. 


\section{קאל סיבויה חד אלאסם מא דכל עליה חרף מן חרוף אלגר

$$
\text { قال سيبويه حد الاسم ما دخل عليه حرف من حروف الجر }
$$

Sibawayhi said: the definition of a noun is what can receive one of the particles that govern the genitive.

In fact, Sîbawayhi did not give a definition of the noun in the Kitāb "The Book", but simply exemplified nouns with rağul "man" and faras "horse." ${ }^{34}$ In the sources a number of definitions are ascribed to Sibawayhi, ${ }^{35}$ but to the best of my knowledge not the one given here. Instead, the above definition strongly resembles a part of the definition given by Abū l-'Abbās al-Mubarrad (d. 285/898) in al-Muqtadab "The Epitome":

$$
\text { كل ما دخل عليه حرف من حروف الجر فهو اسم }
$$

Everything that can receive one of the particles that govern the genitive is a noun. ${ }^{36}$

2) 'Alī b. Abī Ṭālib’s definition of all parts of speech

קאל עלי בן אבי טאלב חד אלאסם מא דל עלי מעני [מס]מאה? ואלפעל אל[מס]מא?

$$
\text { ואלח[ר]ף מא דל [עלי מע][י ......... }
$$

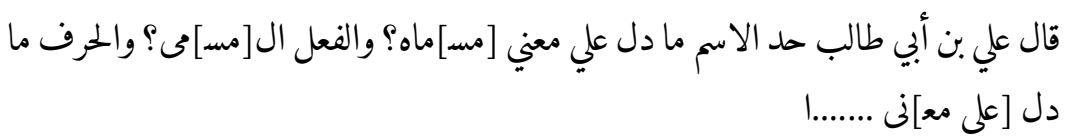

'Alī b. Abì Ṭālib said: the definition of a noun is what signifies the meaning of its nominatum. The verb is the nominatum(?). The particle is what signifies the meaning ...

The passage is not well preserved, and at least the definition of the verb seems corrupt. 'Alī b. Abī Tâalib is frequently named as the initiator of the Arabic grammar in Muslim bibliographical literature. ${ }^{37}$ Whereas Arabic grammatical works

34 Sībawayhi, al-Kitāb, p. 1.

35 Versteegh, Explanation, p. 59 note 8.

36 al-Mubarrad, Kitäb al-Muqtadab, p. 3. See also Versteegh, Explanation, p. $5^{1}$ and p. 62 note 20.

37 See Versteegh, Arabic Grammar, pp. 167-171, 18o. Sezgin, GAS, vol. 9, pp. 5-6. 
do not usually cite definitions of parts of speech ascribed to 'Alī, bibliographical treatises do, for example:

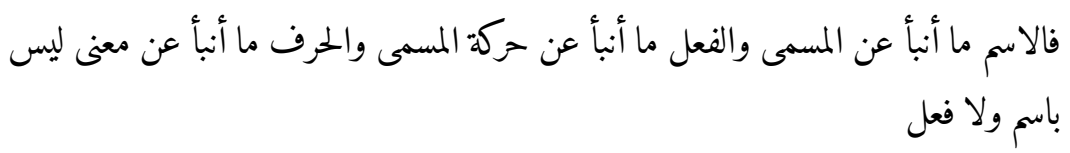

The noun is what gives information about the nominatum. The verb is what informs about the movement of the nominatum. The particle is what gives information about a meaning that is neither that of a noun nor that of a verb. ${ }^{38}$

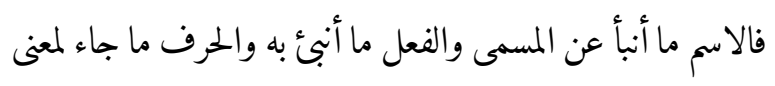

Noun is what gives information about the nominatum. Verb is that by which information is given. Particle is what comes to a meaning. ${ }^{39}$

A set of definitions similar to the one in the former quotation appears to have given rise to the now corrupt version in the Judaeo-Arabic compilation.

3) Aristotle's definition of all parts of speech

ארסטאליס40....

$$
\text { (أرسطاطاليس حد الاسم بعينه والفعل الكلمة والحرف أداة }
$$

... Aristotle: the definition of a noun is exactly the same (i.e. ism), and the verb is "word" (kalima) and the particle is "instrument" (adāt).

This definition establishes correspondences between Arabic grammatical terms for parts of speech (ism, fil and harf) and Arabic translations of Aristotelian terms (ism, kalima and adāt). As is well known, Aristotle divided speech into nouns, verbs and particles, calling them in Greek onoma (lit. "name"), rhema (lit. "word, utterance, thing said") and sundesmos (lit. "some-

38 al-Suyūṭi, al-Ašbāh, "Similarities and Parallels in Grammar", vol. 1, pp. 12-13.

39 Ibn al-Anbārī, Nuzha, "A Promenade of Intelligent People along Generations of Philologists", p. 4. Translated in Versteegh, Greek Elements, p. 6. See also ibid, pp. 45, 72.

40 A haplology for ארסטאטאליס. 
thing that binds together") respectively. These terms were incorporated into medieval Arabic philosophers' discourses on language as ism, kalima and adāt or ribăt. ${ }^{41}$ On the contrary, grammarians used ism, fil and harf. The explicit inclusion of Aristotle's definition is as unexpected as that by 'Alī b. Abī Ṭālib, since it traditionally belongs to logical-philosophical rather than grammatical literature.

4) Al-Dumayk's definition of nouns

אלדמיך חד אלאסם מא דל עלי מעני פי נפסה גיר מקתרן בזמאן מן גיר אן ידל עלי גזו מן אגזא אלגמילה אלדי דל עליה מלל מליה

The Judaeo-Arabic phrase מן גיר אן ידל עלי גזו מן אגזא אלגמילה אלדי דל עליה is corrupt. In the following an attempt has been made to emend the text on the basis of parallel definitions: ${ }^{42}$

$$
\begin{aligned}
& \text { الدميك حد الاسم ما دل على معنى في نفسه غير مقترن بزمان من غير أن يدل (جزؤه> على } \\
& \text { جزء من أجزاء (معناه/43 الذي دل عليه }
\end{aligned}
$$

Al-Dumayk: the definition of a noun is what signifies a meaning with reference to itself, ${ }^{44}$ not connected with time, without $\langle$ a part of it $\rangle$ signifying a part of the meaning that it signifies.

Similar definitions are found in Arabic translations of Aristotles' books and other philosophical-logical works, ${ }^{45}$ and have been listed by al-Zağğăǧñ in al-

41 See Gutas, Avicenna, p. 307; Dunlop, "Al-Fārābī's introductory sections," pp. 270, 278; alFārābī, Ihṣ̂ā', p. 35. See also Versteegh, Greek Elements, pp. 38-54.

42 One of the closest definitions is found in Ibn 'Ușfūr al-Išbīlì, Šarh, "A Commentary on al-

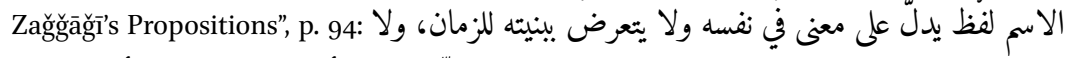
يدلّ جزء من أجزائه على جزء من :من أجزاء معناه.

43 The suggestion to interpret אלגמילה as standing for the original معناه is based not only on parallel definitions but also on a graphic similarity between the final three letters of the גל אזו מן אגזא a جزء من أجزاء (معنى الجملة as part of the meaning of the whole". Although this reconstruction is paleographically plausible, the phrase معنى الجنم generally occurs in Arabic grammars with the sense "the meaning of the clause" and not "the meaning of the whole".

44 I.e. non-contingent meaning.

45 See Versteegh, Greek Elements, pp. 138-140, 217. 
Ị̇āh fí Tlal al-nahww "The Explanation of Linguistic Causes" as definitions which are "taken from the technical language of the logicians" and "do not meet linguistic requirements". 46

The mention of al-Dumayk merits special attention. Manșūr b. al-Muslim b. 'Alī b. Muḥammad b. Aḥmad b. Abī al-Ḩarağayn, known as al-Dumayk (c. 457/ 1060-510/1117), is mentioned in biographical literature as a poet, a teacher and a grammarian. ${ }^{47}$ To the best of my knowledge none of his grammatical works survive. Quotations attributed to al-Dumayk in the Judaeo-Arabic compilation constitute the only source on the grammatical teachings of this scholar known today. Al-Dumayk pursued his career in Damascus, and it may not be a coincidence that he is quoted in a work penned by a scribe who lived in that city at approximately the same time.

In addition to the definition of a noun cited above, the following is transmitted in our fragments in the name of al-Dumayk:

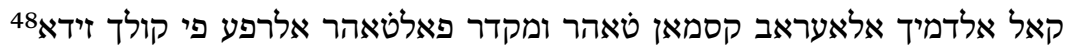

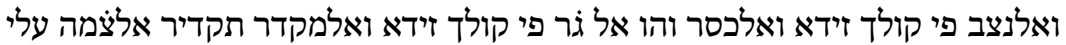

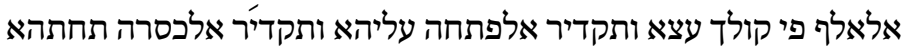

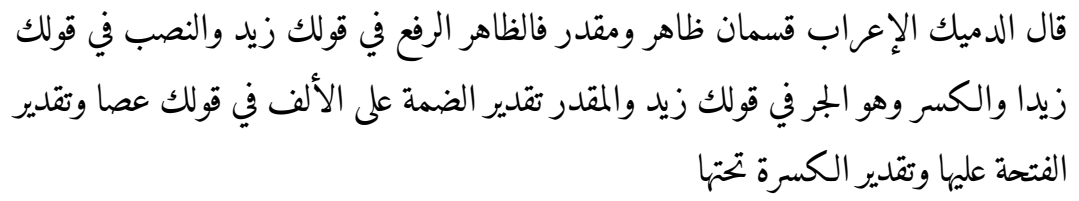

Al-Dumayk said: there are two types of inflection, explicit and virtual. The explicit (inflection) is the nominative as in Zaydun, and the accusative as in Zaydan and the kasr, which is the genitive, as in Zaydin. The virtual (inflection) is the implied damma on the alif as in 'așan, and the implied fatha on it, and the implied kasra under it.

קאל אלדמיך אלחרכאת אבעאץ ללחרוף פלמא כאנת אלחרכאת עלאמה אלאעראב

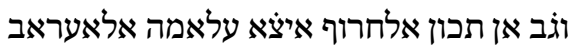

46 Versteegh, Explanation, pp. 49-5o, 59 footnotes 4, 6.

47 Qifțī, Inbāh, "The Report of Storytellers about Famous Grammarians", vol. 3, pp. 326-327; Sezgin, $G A S$, vol. 2, p. 69; Ziriklī, vol. 8, p. 245. In the literature the name can also be vocalised "al-Damīk."

48 On the spelling of the tanwin here and in other Judaeo-Arabic grammars of Classical Arabic see Vidro, "Arabic vocalisation". 


\section{قال الدميك الحركات أبعاض للمروف فلما كانت الحركات علامة الإعراب وجب أن تكون الحروف أيضا علامة الإعراب}

Al-Dumayk said:vowels are parts of letters. Inasmuch as vowels are markers of inflection, by necessity letters are markers of inflection, too.

The next passage explains the term "weak annexed nouns" (asmä mu'talla mudāafa) used for the five nouns $a b, a h, f \bar{u}$, ham and $\underline{d} \bar{u}$ :

קאל אלדמיך אנמא סמית אלאסמא מעתלה לאן אעראבהא בחרוף אלעלה ואלה וחרוף

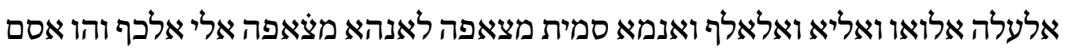

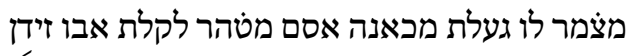

$$
\begin{aligned}
& \text { قال الدميك إنما سميت الأسماء معتلة لأن إعرابها بحروف العلة وحروف العلة الواو والياء }
\end{aligned}
$$

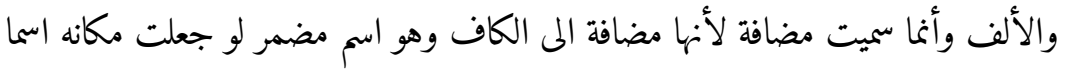

$$
\begin{aligned}
& \text { مظهرا لقلت أبو زيد }
\end{aligned}
$$

Al-Dumayk said: they are called weak nouns because their inflection is by means of weak letters, and weak letters are waw, $y \vec{a}$, and alif. They are called annexed because they are annexed to $k \bar{a} f$, which is a pronoun (lit. a hidden noun). If you used an explicit noun instead, you would say $A b \bar{u}$ Zaydin.

JTS ENA 3173.1 (1 Folio), T-S Ar 31.30 (1 Folio), Manchester Rylands B $365^{2}$ (1 Folio), Manchester Rylands B 3653 (1 Folio), Paris AIU IX.A.6 (1 Folio) ${ }^{49}$ End of the 11th-12th-Century Handwriting The five fragments belong together and contain a description of Classical Arabic that does not belong to the Arabic grammatical tradition. Rather they use concepts and terminology characteristic of philosophers and logicians and scholars familiar with Greek grammar. The fragments explicitly mention the Greeks and Galen.

49 Edited in Vidro, "A book on Arabic inflexion". ENA 3173.1 is described with excerpts in Maman, Otsrot Lashon, pp. 522-523. T-S Ar 31.30 is transcribed and translated into Hebrew on the website of the Friedberg Jewish Manuscript Society https://fjms.genizah.org. Multiple lacunae make an unambiguous reconstruction of the order of pages impossible, but the text clearly starts on ENA 3173.1 directly followed by T-S Ar 31.30. 
The work is divided into discourses (maqālāt) devoted to different aspects of grammar (funūn al-naḩw). The first discourse is not preserved but references to it in the beginning of the second discourse testify that it dealt with parts of speech. The second discourse is dedicated to the correct pronunciation of utterances (qiräat al-kalām 'alā l-șawāb) by using the appropriate vowels, hamza and tanwīn, and eliding such letters as alif, nūn, waw and $y \bar{a}$ ' where necessary. In the introduction it is announced that the discourse will present the inflection of different parts of speech using rules "known to the Greeks as kanons (qawānin)". Due to the state of the manuscripts, it is not clear whether all preserved text belongs to this discourse, but inflection rules are the main subject matter in all fragments.

Two examples will suffice to demonstrate the fragments' connection with Greek grammar and the philosophical-logical tradition of language description. The first example concerns the terminology for grammatical persons. In Arabic linguistics grammatical persons are referred to by the terms almutakallim (the speaker), al-muhățab or al-muhāțab al-muwāğah (the addressee) and $a l-\dot{g} \bar{a} i b$ (the absentee). In contrast, the author of the fragments uses the terms first, second and third persons (lit. "faces", wağh, awğuh): ${ }^{50}$

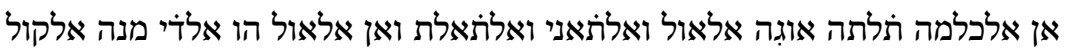

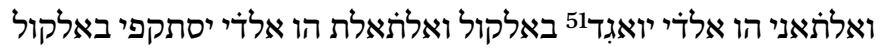

$$
\begin{aligned}
& \text { إن الكلمة ثلاتة أوجه الأول والثاني والثالث وإن الأول هو الذي منه القول والثاني هو الذي } \\
& \text { يواجه بالقول والثالث هو الذي يستقنى بالقول }
\end{aligned}
$$

A verb has three persons (awğuh): the first, the second and the third. The first is from whom the utterance is. The second is who is addressed with the utterance. The third is who is pursued ${ }^{52}$ by the utterance.

$5^{\circ}$ In the annotated Hebrew translation of T-S Ar 31.30 on the website of the Friedberg Jewish Manuscript Society, the three facets are understood as referring to the three cases. As the following quotation demonstrates, this interpretation is untenable.

51 Read יואגִה.

52 The term yustaqfā bi-l-qawl is not entirely clear. The root q.f.w. expresses the general idea of "following". Form X of the root q.f. $w$ usually means "to strike someone on the neck" and can also mean "to make someone to follow someone or something" and "to avail oneself of somebody's absence (in order to do something behind his back)". The meaning "to pursue, to examine, to study" is suggested by Blau in one case (Blau, Dictionary, p. 559). An alternative translation may be "somebody who is construed as absent by the utterance". I thank Geoffrey Khan for this suggestion. 
The term wağh for a grammatical person is a translation of the Greek prosopon (lit. "face", "mask"). It was used by a renown Arabic philosopher and logician al-Fārābī (d. 339/95o) in a section on the discipline of grammar in the classification of the sciences Ihșẫ al-ulüm "Enumeration of the Sciences". ${ }^{33}$ The above given definition itself strongly resembles the Greek definition by Dionysius Thrax in Tekhne Grammatike "The Art of Grammar", which in a literal translation reads:

There are three persons, first, second and third. The first is from whom the utterance is. The second is to whom the utterance is. And the third is about whom the utterance is. ${ }^{54}$

The second example concerns parts of speech. In contrast to the traditional division of speech into nouns (ism), verbs $\left(f^{i} l\right)$ and particles (harf) accepted among Arab grammarians, the author categorised Arabic speech into seven parts:

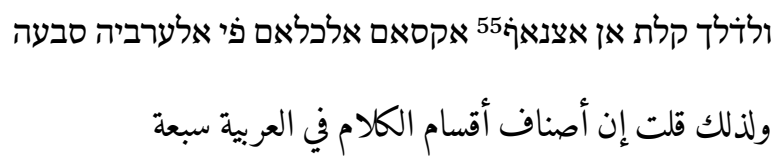

This is why I said that in Arabic there are seven types of parts of speech.

Although the relevant discourse has not survived, the text operates with the following categories: ism, kalima, rābiț, hălifa, wāsița, wāṣila, hāšìa. The same seven categories are found in al-Fārābī's treatise on logic Kitāb al-Alfāz almusta'mala fi l-mantiq "A Dictionary of Terms Used in Logic": ism (noun), kalima (verb), hawālif (substitutes/pronouns), wāsilāt (articles, including particles of definiteness, e.g. al-, alladi, the vocative $y \bar{a}$, etc.), wāsițāt (intermediaries/prepositions), hawāšin (commentative particles, including particles confirming existence, e.g. inna, and particles of negation, e.g. laysa, lāa, etc.), and rawābit (binding elements/conjunctions, e.g. imma, in kāna, etc.). ${ }^{56} \mathrm{Al}-\mathrm{Fā}$ rābī contrasts the logicians' term kalima with the grammarians' term $f i$, both used to denote verbs, and explains that Arab grammarians have no vocabulary for different kinds of particles ( $h u r u \bar{f}$ ) making it necessary for him to use Greek

53 al-Fārābī, Ihșā̄, p. 21. See also Versteegh, Greek Elements, p. 62 note 53 .

54 Dionysius Thrax, Tekhnē Grammatikē, p. 51.

55 Every letter $p e h$ in the fragment is marked with an oblique stroke above the letter.

56 al-Fārābī, Kitāb al-Alfāz, pp. 41-56. See also Gaetje, "Die Gliederung;" Haddad, "Alfārābi's views," pp. 205-207; Eskenasy, "Al-Fārābī’s classification". 
grammatical terms instead. ${ }^{57}$ Although no definitions of the seven categories survive in the Judaeo-Arabic fragments, it is likely that they had the same meaning as in Kitāb al-Alfäz.

Some information on the text's author can be extracted from the fragments, in addition to his knowledge of the Greek grammatical tradition and Galen. While discussing the division of speech into intonation units, the author mentions his mastery of Classical Greek and Syriac together with some familiarity with Persian, Byzantine Greek, and Coptic:

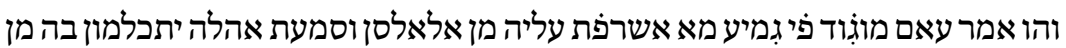

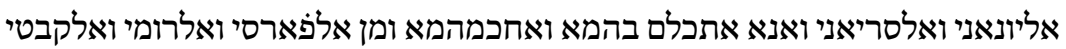

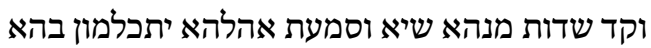

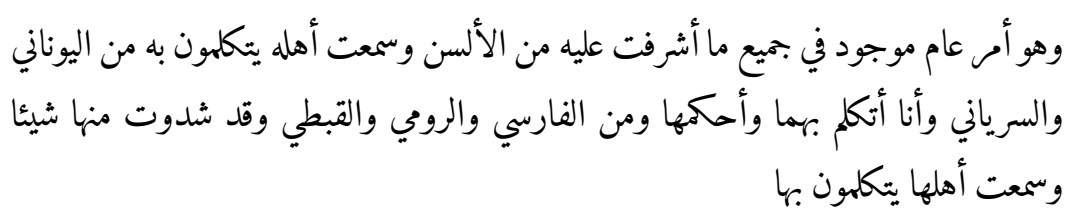

This is a general issue found in all languages that I am acquainted with and have heard people speak, including Greek and Syriac, which I speak proficiently, as well as Persian, Byzantine Greek and Coptic, which I know a little and have heard people speak them.

In examples illustrating various points of grammar the author sometimes uses the name Abū Zayd and once the name Hunayn. Whereas the use of Abū Zayd in examples is common, that of Hunayn is extremely rare. In the Greek tradition, grammarians tended to use their own names or those of their teachers in giving examples, ${ }^{58}$ and it is not impossible that the same may be the case in our grammar. The names Abū Zayd and Hunayn, together with the author's knowledge of Greek, Syriac, Persian, Greek terminology and Galen, allow putting forward a tentative hypothesis that the fragments are associated with Abu Zayd Ḥunayn b. Ishạāq al-'Ibādī (8o9-873), a famous physician, philosopher, and translator of Galen and other Greek works..$^{59}$ Indeed, Ḥunayn is said to have

al-Fārābī, Kitāb al-Alfāz, pp. 41-42. On the Greek origins of this terminology see Versteegh, Greek Elements, pp. 51-54, 121-122; Gaetje, "Die Gliederung”; Eskenasy, “Al-Fārābī’s classification," pp. 65-78.

$5^{8}$ Versteegh, Greek Elements, pp. 39-40 and footnote 11 there.

59 On Ḥunayn b. Isḥāq and his works see Sa'di, "A bio-bibliographical study;" Bergsträsser, Hunain ibn Ishaq; Meyerhof, "New Light". 
composed a book on Arabic inflection according to the Greek system in two discourses (maqualatān), no copies of which have so far been identified. ${ }^{60}$

\section{Concluding Remarks on the Corpus of Grammars of Classical Arabic in Judaeo-Arabic}

Grammars of Classical Arabic copied in Hebrew characters are interesting from two perspectives. Firstly, they furnish new material on the history of the Arabic grammatical tradition. These manuscripts complement Muslim sources on the subject by preserving otherwise unknown texts, some of which do not belong to the mainstream of the Arabic grammatical tradition. In the corpus presented above there are three examples of this- the Küfan pedagogical primer (item 5), quotations from al-Dumayk (item 6) and a grammar of Classical Arabic possibly associated with Ḥunayn b. Ishạāq (item 7).

Secondly, grammars of Classical Arabic in Judaeo-Arabic are important because they testify to Jews' active interest in grammar other than the grammar of Biblical Hebrew. One of the most challenging questions that arises in connection with the corpus is whether Jews composed any of the treatises or simply transliterated Muslim works. In the present state of research it is impossible to give a definitive answer. On the one hand, not all fragments could be identified with Muslim grammars. On the other hand, no anonymous grammars known to me carry explicit indications of Jewish authorship. Hebrew is never mentioned, either for comparisons with Arabic or as a language that an author masters. Hebrew terminology, which is often found in Judaeo-Arabic works on Hebrew grammar, is equally absent. The Küfan primer (item 5 ) was clearly copied from a Vorlage in Arabic script, and the adaptation of al-Luma'fíl-arabiyya (item 1) contains additional quotations from the Qurān not found in the original text. Although these facts do not preclude Jewish authorship, they make it less probable. Of all texts discussed here, the compilation of language-related materials in item 6 seems less likely to have been copied as a whole, and may have been put together by a Jew.

Even if simply transliterated from Muslim works, the fragments bear clear evidence of Jewish engagement with Classical Arabic grammar for its own sake

6o This work is listed in Ibn Nadīm's Fihrist "Catalogue" as Kitāb Ahkām al-írāb 'alā mad̆hab al-yūnāniyyìn "Book on the Rules of Inflection according to the System of the Greeks" (see Ibn al-Nadīm, Kitāb al-Fihrist, vol. 1, p. 294). See also Merx, Historia, pp. 105-106; Sa'di, p. 436, no. 171; Sezgin, GAS, vol. 9, pp. 232-233. Serikoff, "The Greek verbal lemmas" proposed an alternative theory that this work was a grammar of the Greek language. 
rather than as a theoretical framework for analysing Biblical Hebrew. What grammars were Jews interested in? When attempting to assess the corpus, one cannot help noticing that major foundational works of Arabic grammar, such as Sībawayhi's Kitāb, al-Muqtada ab by al-Mubarrad, Kitāb al-Ușūl by Ibn al-Sarrāj, are absent. This contrasts with the extensive use made of these grammars by Hebrew grammarians. ${ }^{61}$ All identifiable grammars in the corpus are textbooks for beginners that lay out the facts of Arabic syntax while only briefly delving into theoretical discussions. ${ }^{62}$ The anonymous grammars in this corpus are of the same type. It is then clear that Jews who copied and used these texts were less interested in the intricacies of abstract theory than in attaining a solid knowledge of Classical Arabic. The use of a portion from Kitāb al-Ğumal by alZağğăğği (item 2) as a vocalisation exercise supports this conclusion.

It is difficult to know whether Jews who intended to copy and study Classical Arabic grammars relied solely on written books or participated in study-circles. On the one hand, Šarh Mulhat al-íräb (item 3) and the Küfan primer (item 5) have multiple transliteration mistakes conditioned by the shapes of Arabic letters and letter combinations. Such mistakes are impossible when texts are studied with a teacher. ${ }^{63}$ On the other hand, quotations from al-Dumayk, a teacher of children and grammarian who worked in Damascus, included in a haphazard compilation of grammatical materials (item 6) in the hand of Nathan b. Samuel, a native Damascene who lived in the city in nearly the same period, may indicate that Nathan b. Samuel attended a study-circle in Damascus. ${ }^{64}$

The fact that two of the manuscripts (items 5 and 6) are copied in the hands of well-known court scribes may mean that scribes were among those interested in the study of Classical Arabic grammar. Admittedly, it is likely that scribes did not generally copy works for their own consumption. These manuscripts, however, do not give the impression of having been copied for a

61 Becker, Arabic Sources of R. Jonah ibn Janāh, pp. 53-59; Basal, "Part one".

62 See Carter, "Arabic grammar," p. 131; Baalbaki, "Theoretical coherency".

63 Incidentally, numerous transliteration mistakes in quotations from the Qurän and Arab poetry, which are commonly used in Arabic grammars to demonstrate grammatical phe-

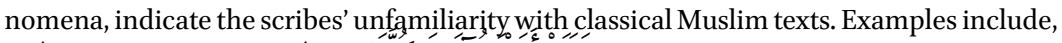
in Qurān 20:56 (Vidro, Kasher, "A Kūfan

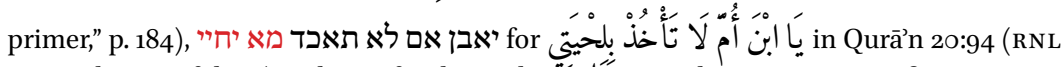

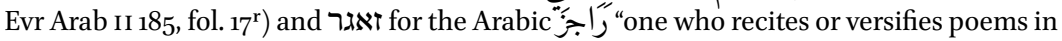
the meter rağaz" (RNL Evr Arab II 185, fols. 19 ${ }^{\mathrm{r}}, 24^{\mathrm{r}}, 24^{\mathrm{v}}$ ), which betrays unfamiliarity with the poetic meter rağaz.

64 For a study-circle in Damascus in the house of a shaykh learned in grammar and the rational sciences, attended by Muslims, Jews, Christians, heretics and Samaritans, see Chamberlain, Knowledge and Social Practice, p. 84 note 8 o. 
customer. The Küfan primer in the hand of Hillel b. 'Eli is a faulty copy on scrap paper. The compilation in the hand of Nathan b. Samuel is a poorly organised and unfinished collection of materials. Both appear to be the scribes' private books prepared with the intention of studying Classical Arabic grammar.

\section{Acknowledgments}

I am grateful to Dr Almog Kasher (Bar-Ilan University) for discussing the material with me at all stages in the preparation of this paper. Without his expert advice this paper would have been deficient in very many ways. I thank Dr Amir Ashur (Tel Aviv University) for his help assessing the manuscripts' handwriting and identifying scribes. All mistakes are mine.

\section{Bibliography}

\section{Primary Sources}

Ibn al-Anbārī, Abū l-Barakāt, Nuzhat al-alibbä’’ tịtabaqāt al-udabä’, ed. 'A. Amer, Stockholm: Almqvist \& Wiksell, 1963.

Dionysius Thrax, Tekhnē Grammatikē, ed. G. Uhlig, Dionysii Thracis Ars grammatica, Leipzig: B.G. Teubneri, 1883 .

al-Fārābī, Abū Naṣr, Ihṣă’ al-ulūm, ed. 'A. Bū Mulahḥam, Beirut: Dār wa-Maktabat alHilāl, 1996.

al-Fārābī, Abū Nașr, Kitāb al-Alfāza al-mustámala fì l-manțiq, ed. M. Muḥsin, Beirut:Dār al-Mashriq, 1968.

al-Ḥarīīī, Abū Muḥammad al-Qāsim ibn 'Alī al-Bașrīi, Šarh mulhat al-írāb, ed. F. Fāris, Irbid: Dār al-'Amal li-l-Našr wa-l-Tawzī', 1991.

Ibn Janāh, Jonah, Kitāb al-Luma', ed. J. Derenbourg, Le Livre des parterres fleuris. Grammaire hébrä̈que en Arabe D'Abou'l-Walid Merwan ibn Djanah de Cordoue, Paris: F. Vieweg, 1886.

al-Mubarrad, Abī l-'Abbās Muhammad ibn Yazīd, Kitāb al-Muqtaḍab, ed. M.'A. 'Uḍaymah, Cairo, 1963.

Ibn al-Nadīm, Kitāb al-Fihrist, ed. G. Flügel, Leipzig: F.C.W. Vogel, 1872.

al-Naḥhās, Abū Ğa far, Al-Tuffāha fí l-naḥw, ed. K. 'Awwād, Baghdad: Maṭba'at al-Ānī, 1965 .

Qifțī, 'Alī b. Yūsuf, Inbāh al-ruwāh 'alā anbāh al-nuhāhh, ed. M. Ibrāhīm, Cairo: Dār alKutub al-Mișriyya, 1950.

Sïbawayhi, al-Kitāb, ed. H. Derenbourg, Le livre de Sîbawaihi, Paris: L'Imprimerie National, $1881-1889$. 
al-Suyūṭ̂̄, Jalāl al-Dīn 'Abd al-Raḥmān ibn Abī Bakr, Al-Ašbāh wa-l-nażā̉ir fíl-naḥw, ed.

'A. al-S. Mukarram, Beirut: Al-Risāla, 1985.

Ibn 'Ușfūr al-Išbīlī, 'Alī b. Mu’min, Šarh ğumal al-Zağǧāăḡi, ed. Ṣ Abū Janāḥ, Baghdad: Wizārat al-Awqāf wa-l-Šu'ūn al-Dīnīyah, 1980.

al-Zağğāḡī, Abū l-Qāsim 'Abd al-Raḥmān b. Isḥāq, Kitāb al-Ǧumal fíl-nạ̣w, ed. 'A.T. alHamad, 5th ed, Beirut: Al-Risāla, 1996.

\section{Secondary Literature}

Baalbaki, R., "Introduction: The early Islamic grammatical tradition," The Early Islamic Grammatical Tradition, ed. R. Baalbaki, Aldershot: Ashgate, 2007, pp. xiii-l.

Baalbaki, R., "Theoretical coherency versus pedagogical attainability: The conscious bias of Arab grammarians," Alltagsleben und materielle Kultur in der arabischen Sprache und Literatur: Festschrift für Heinz Grotzfeld zum 70. Geburtstag, eds. Th. Bauer, U. Stehli-Werbeck, Wiesbaden: Herrassowitz Verlag, 2005, pp. 39-68.

Basal, N., "Mediaeval Jewish and Muslim cultures: An anonymous Judaeo-Arabic adaptation of Ibn Jinnī's al-Luma', Jerusalem Studies in Arabic and Islam 37 (2010), pp. 223-263.

Basal, N., "A medieval Jewish grammar of Classical Arabic: The attribute in a JudeoArabic adaption of Ibn Ğinni’s Al-luma," Zeitschrift für Arabische Linguistik 47 (2007), pp. 6o-79.

Basal, N., "Part one of al-Kitāb al-muštamil by Abū al-Faraj Hārūn and its dependence on Ibn al-Sarrāj's Kitāb al-uṣūl fi al-naḥw," Leshonenu 61 (1998), pp. 191-209 [in Hebrew].

Becker, D., Arabic Sources of Isaac ben Barūn's “Book of comparison between the Hebrew and the Arabic languages," Tel-Aviv: Tel-Aviv University Press, 2005 [in Hebrew].

Becker, D., Arabic Sources of R.Jonah ibn Janāḥ's Grammar, Tel-Aviv:Tel-Aviv University Press, 1998 [in Hebrew].

Becker, D., "The dependence of R. Yona b. Ğanāḥ on Arabic grammarians," Leshonenu 37/2 (1992), pp. 137-145 [in Hebrew].

Bergsträsser, G., Hunain ibn Ishaq, über die syrischen und arabischen Galen-Übersetzungen, Abhandlungen für die Kunde des Morgenlandes 17/2, Leipzig, 1925.

Binaghi, F., La postérité andalouse du Ğumal d'al-Zağǧăğğ (unpubl. diss., University D' Aix-Marseille), 2015.

Blau, J., Dictionary of medievalJudaeo-Arabic texts, Jerusalem: Academy of Hebrew Language, Israel Academy of Science and Humanities, 2006.

Carter, M.G., "Grammatical tradition: History", Encyclopedia of Arabic Language and Linguistics, eds. of the online edition L. Edzard, R. de Jong. Consulted online on o5 October 2017 http://dx.doi.org/10.1163/1570-6699_eall_EALL_COM_vol2_oo28. First published online: 2011.

Carter, M.G., "Arabic Grammar," Religion, Learning and Science in the 'Abbasid Period, eds. M.J.L. Young, J.D. Latham, R.B. Serjeant, Cambridge: CUP, 1990, pp. 118-138. 
Chamberlain, M., Knowledge and Social Practice in Medieval Damascus, 1190-1350, Cambridge: CUP, 1994.

Dunlop, D.M., "Al-Fārābī’s introductory sections on logic," Islamic Quarterly 2/4 (1955), pp. $264-282$.

Eskenasy, P., "Al-Fārābī's classification of the parts of speech," Jerusalem Studies in Arabic and Islam 11 (1988), pp. 55-82.

Fleisher, E., "From the diwan of the secular poetry of R. Nathan ben Samuel Nezer haHaverim," Kovets Al Yad 18 (2005), pp. 139-196 [in Hebrew].

Gaetje, H., "Die Gliederung der sprachlichen Zeichen nach al-Fārābī", Der Islam 47 (1971), pp. 1-24.

Gil, M., In the Kingdom of Ishmael, Tel-Aviv: Tel-Aviv University, 1997 [in Hebrew].

Gutas, D., Avicenna and the Aristotelian Tradition: Introduction to Reading Avicenna's Philosophical works, 2nd ed, Leiden: Brill, 2014.

Haddad, F., "Alfārābi's views on logic and its relation to grammar," Islamic Quarterly 13 (1969), pp. 192-207.

Hämeen-Anttila, J., "Abū Muḥammad al-Qāsim al-Ḥarīn̄," Essays in Arabic literary biography, vol. 1, 925-1350, eds. T. DeYoung and M. St. Germain, Wiesbaden: Harrassowitz, 2011, pp. 66-74.

Khan, G., Arabic Legal and Administrative Documents in the Cambridge Genizah Collections, Cambridge: CUP, 1993.

Langermann, Y.Tz., "Arabic writings in Hebrew manuscripts: a preliminary relisting," Arabic Sciences and Philosophy 6 (1996), pp. 137-16o.

Maman, A., Otsrot Lashon: The Hebrew Philology Manuscripts and Genizah Fragments in the Library of the Jewish Theological Seminary of America, New York: JTSA, 2006 [in Hebrew].

Merx, A., Historia artis grammaticae apud Syros, Abhandlungen für die Kunde des Morgenlandes 9/2, Leipzig, 1889 .

Meyerhof, M., "New light on Hunain Ibn Ishaq and his period," Isis 8/4 (1926), pp. 685724 .

Rustow, M., "A petition to a woman at the Fatimid court (413-414A.H./1022-1O23 C.E.)," Bulletin of the School of Oriental and African Studies 73 (2010), pp. 1-27.

Sa'di, L.M., "A bio-bibliographical study of Hunayn Ibn Ishaq Al-Ibadi," Bulletin of the Institute of the History of Medicine 2 (1934), pp. 409-446.

Sabra, A.I., "The appropriation and subsequent naturalization of Greek science in medieval Islam: a preliminary statement," History of Science 25 (1987), pp. 223243 .

Serikoff, N., "The Greek verbal lemmas from the Lexicon by Bar Bahlul, their origin and the lost work by Hunayn ibn Ishaq 'Principles of i'rāb according to the Greek scholars," Orientalistica 1/1 (2018), pp. 45-65 [in Russian].

Sezgin, F., Geschichte des Arabischen Schrifttums, Leiden: Brill, 1984. 
Versteegh, C.H.M., Explanation of Linguistic Causes: al-Zağğğăğı Theory of Grammar: Introduction, Translation, Commentary, Amsterdam: J. Benjamins, 1995.

Versteegh, C.H.M., Arabic Grammar and Qur'ānic Exegesis in Early Isalm, Leiden: Brill, 1993.

Versteegh, C.H.M., Greek Elements in Arabic Linguistic Thinking, Leiden: Brill, 1977.

Vidro, N., "A book on Arabic inflexion according to the system of the Greeks," ZAL, Journal of Arabic Linguistics (forthcoming)

Vidro, N., "Arabic vocalisation in Judaeo-Arabic grammars of Classical Arabic," in Studies in Semitic Linguistics and Manuscripts, eds. N. Vidro et al, Uppsala: University of Uppsala Press, 2018, pp. 341-351.

Vidro, N., A. Kasher, "How medieval Jews studied Classical Arabic grammar: a Kūfan primer from the Cairo Genizah," Jerusalem Studies in Arabic and Islam 41 (2014), pp. 173-244.

Weil, G., Die grammatischen Streitfragen der Basrer und Kufer, Leiden: Brill, 1913.

Weiss, G., Hillel ben Eli: Documents written by Hillel ben Eli: A study in the diplomatics of the Cairo Geniza documents (unpublished MA thesis, University of Pennsylvania), 1967.

Zabara, H., Perspectives on Tenth Century Arabic Grammar Al-Zajjaji’s “Jumal” (unpubl. diss., Georgetown University), 2005.

Ziriklī, K., Al-A lām: Qāmūs tarāğim li-ašhar al-riğāl wa-l-nisā’min al-Arab wa-l-mustaribìn wa-l-mustašriqin, 2nd ed., Cairo, 1954-1959. 